\title{
The Harmony in Instructional Communication to Create a Comfortable Learning Atmosphere
}

\author{
I Wayan Rasna* \\ Prodi Pendidikan Bahasa Inggris \\ Universitas Pendidikan Ganesha Singaraja \\ Bali, Indonesia \\ *wayanrasna@ymail.com
}

\author{
Ni Wayan Sariani Binawati \\ Prodi Dharma Acarya \\ Institut Hindu Dharma Negeri Denpasar \\ Bali, Indonesia \\ wsbinawati@yahoo.com
}

\author{
I Nyoman Tri Anindia Putra \\ Prodi Teknik Informatika \\ Sekolah Tinggi Ilmu Komputer Indonesia \\ Bali Indonesia \\ trianindiaputra@gmail.com
}

\begin{abstract}
The main purpose of teaching is to optimally create a comfortable learning atmosphere through a harmony in instructional communication to obtain an optimal learning achievement. An optimal learning achievement is determined among others by the increasingly fluent language ability of the learner. The more fluent his or her language ability, the more fluent his or her thinking and the more successful his or her learning will be. Success is determined by $20 \%$ hard skill and $80 \%$ soft skill, and the language norm is one of the factors. The sample of this study was selected purposively from senior high schools and vocational schools in Singaraja. The data were collected through observation and interview. The result showed that the harmony in instructional communication in creating a comfortable learning atmosphere was dominantly $(\mathbf{8 0} \%)$ determined by the readiness of the teacher to understand the students' condition, for example, his or her willingness to lose (ready to control himself or herself) by not protracting an emotional condition. On the contrary, the teacher showed respect, solidarity, polite attitude and behavior to the students. On this basis, it is suggested to teachers to show a polite attitude and to speak politely to the students. For example, the teacher greets the students rather than the students great the teacher.
\end{abstract}

Keywords: harmony, communication, atmosphere, learning, comfortable

\section{INTRODUCTION}

Comfort in learning becomes a dream of every student. However, this is not easy to get. This study tried to study factors that influence a harmony in instructional communication that brings with it energy and orientation toward positive learner behavior [1], and strategies to create harmony in instructional communication [2]. Giving an actual contextual example with local wisdom content contributes positively to harmony in instructional communication $[3,4]$, that is relevant to the contemporary condition of the learners
[5], in addition to its contribution to motivation to learn languages [6]. Learning motivation is also influenced by teacher strategy in giving instructions, greeting, asking for something [7]. These teacher strategies are very influential to harmony in learning and its success, so that the student linguistic politeness as an effort to condition polite speech is an important part of character education [8], since comfortable learning atmosphere starts from the use of language in learning [9], such as the values taught through lontar wratisasana (the lontar that guides behavior). Moreover, comfortable language communication is taught through conditioning based on local culture through relevant folktales [10]. Through these media children learn how to interact in harmony with their peers, with God, and nature.

A harmonious communication interaction aims to get an optimal learning achievement [11,12]. Success is determined by more or less $20 \%$ hard skill and $80 \%$ soft skill [13]. Language norm is one of them [14-16], beside the cultural aspect that is intrinsically integrated with the language system as shown by the speaker's culture (speech style). Unfortunately, the interest of Indonesian language observers to study the realization of speech in Indonesian speech community is still very low, although on the other hand, it is realized that the problem of speech is very crucial in success in communication [17]. Learners will respond positively if the learning communication is comfortable [18].

\section{METHODS}

\section{A. Design}

This study was designed using a qualitative approach to reveal carefully a social phenomenon [19], as a realization of the ideal real system of the superstructure that becomes the guidance for human beings to act in their socio-cultural environment [20]. 


\section{RESULTS AND DISCUSSION OF THE STUDY}

\section{B. Subject and Object of the Study}

The subjects of this study were determined through purposive sampling using the students and teachers of senior high schools and vocational schools (SMAs and SMKs) in Singaraja city and the object of this study was the form of teacher speech that influences the harmony in communication in teaching and the teacher strategies to create a harmony in communication in learning.

\section{Data Collected and Techniques of Data Collection}

The data were collected based on the social principle, that is, the form of speech and the ways the teachers create a harmony in instructional communication. Based on these the data collected and the techniques of collecting them are as follows table 1 .

TABLE I. DATA COLlECTED AND THE TECHNIQUES OF COLLECTING

\begin{tabular}{|l|l|l|l|}
\hline No & \multicolumn{1}{|c|}{ Problem } & \multicolumn{1}{|c|}{$\begin{array}{c}\text { Data that were } \\
\text { collected }\end{array}$} & \multicolumn{1}{c|}{$\begin{array}{c}\text { Techniques of } \\
\text { Data Collection }\end{array}$} \\
\hline 1. & $\begin{array}{l}\text { What are the factors } \\
\text { that influence } \\
\text { harmony in } \\
\text { instructional } \\
\text { communication in } \\
\text { creating } \\
\text { comfortable } \\
\text { academic } \\
\text { atmosphere? }\end{array}$ & $\begin{array}{l}\text { Lesson Plans, forms } \\
\text { of teacher and } \\
\text { student speeches }\end{array}$ & $\begin{array}{l}\text { Recording, } \\
\text { Observation, and in- } \\
\text { depth interview }\end{array}$ \\
\hline 2 & $\begin{array}{l}\text { What strategies are } \\
\text { used by teachers to } \\
\text { create a harmonious } \\
\text { instructional } \\
\text { communication? }\end{array}$ & $\begin{array}{l}\text { Strategies in } \\
\text { presenting lessons }\end{array}$ & $\begin{array}{l}\text { Recording, } \\
\text { observation, } \\
\text { interview, and } \\
\text { documentation }\end{array}$ \\
\hline
\end{tabular}

\section{Techniques of Data Analysis}

By keeping the approach and characteristics of the study, analysis of data of this study was done continuously from the beginning to the end of the stages of the study as follows.

- Arranging the collected data;

- Categorizing the data in terms of concept, proposition, pattern based on similarities or things that can be taken as similar;

- Interpreting the data;

- Formulating a temporary conclusion based on data similarities;

- The verification of the temporary conclusion based on validation;

- Revising and refining the formulation of the conclusion;

- Interpreting the conclusion by looking for the relation between ideological things and problems of the study [21].
A. Factors that Influence the Harmony of an Instructional Communication in Creating a Comfortable Learning Atmosphere

- The teacher understood the materials that he or she taught. Effective communication conveys the right information, enables others to know an individual's feelings and meanings, expresses a kind attitude, and to a certain extent, helps to avoid interpersonal conflict and decrease misunderstanding. Therefore, communication issues not only belong to the field of psychology but also the field of sociology. Instructional communication is the cornerstone of a relationship with a student and teacher [22]. Communication may reduce strategic uncertainly by allowing participants to gain information. Communication also provides opportunities for members of a group to learn about the strategies, preferences, and degree of risk aversion of other members as well as established common information across the group [23].

- Presenting the material using a simple language with complete structures, dictions that were suitable to the students' development.

A simple language for:

○ Elementary school children

Example: wash your hands before eating.

○ Junior high school students

Example: Wash your hands before eating to make them clean to prevent a disease.

- Presentations like those in point (2) will influence the students' understanding.

- The environment that influences the students' thoughts at the time of learning, both the internal such as books, the teacher's language, concentration, obscured instruction and the external such as the teacher- students communication distance; at the time the teacher explains something, the student was absent; noise.

- A humanizing language is the language that is capable of motivating the students to be always enthusiastic to achieve, although it does not mean that it is prohibited to give a punishment to the students who do not do their tasks, or making a mistake. Punishment has obviously to be given to the students who make a mistake, but it should not be in the form of a verbal abuse that has a negative psychological effect. That is why it is important to use a humanizing language. For example, do not use the word "stupid" to refer to a student who fails to understand an instruction. The word needs to be replaced with the word "slow." 
- Teacher: Then, please continue do it at home!

- Student: All right, Miss.

e) Transforming a refusal into a motivation through a modified form:

- Student: Just ten minutes to go!

- Teacher: Yes, ten minutes is still a long time and it is enough to help your friends so that they will understand the lesson.

\section{CONCLUSION}

- The factors that influence the harmony in an instructional communication in creating a comfortable learning atmosphere, are: (a) the teachers understand the material they teach, (b) presenting the material using a simple language, with complete structures, the dictions are suitable with the students' level of development, (c) cognitive ecology, and (d) a humanizing language

- The teachers' strategies to create the harmony in an instructional communication, are: (a) the use of an honorific term of address, (b) the use of a motivator's strong energy words, and (c) motivation in the form of verbal reminder, request to do something, giving an example, prolonging the time, transforming a refusal into a motivation through the use of ameliorated forms.

\section{ACKNOWLEDGMENTS}

The authors would like to thank Director of Postgraduate Studies of Universitas Pendidikan Ganesha, Head of schools, teachers and students of senior high schools and vocational schools in Singaraja city, and all administration staff of Postgraduate Studies of Universitas Pendidikan Ganesha for everything that has made it possible for the authors to finish this study.

\section{REFERENCES}

a) Verbal reminder: Example: Now we are already in March, the fourth week. If this sentence is spoken to a twelfth year student of a senior high school, it becomes a verbal reminder to study harder.

b) Request to do something: Example: Let's learn to become good writers and talented.

c) Giving an example: Example: When the sun starts to set, the sky is red and orange making the horizon look very beautiful. That is when I feel how beautiful God's creation is.

Example:

d) Prolonging the time:

- Teacher: The bell is ringing. Please collect your works!

- Student: Not yet, Miss (the students answered in unison)
[1] T. Kristina and Swinburne, "One-To One Learning and Self Determination Theory," International Journal of Instruction, vol.12, no. 2, p1-16, 2019.

[2] F. Jalil and H. Razieh, "The Contribution of Listening Strategy Instruction to Improving Second Language Listening Comprehension: A Case of Iranian EFL," International Journal of Instruction, vol. 12, no. 2 pp. 17-32, 2019.

[3] I Wayan Rasna and Dewa Komang Tantra, "Reconstruction of Local Wisdom for Character Education through the Indonesian Language Learning :An Ethno-Pedagogical Methodelogy," Theory and Practice in Language Studies, vol.7, no.12, pp. 1229-1235, 2017.

[4] A.Z. Hanan, A. Nabil and M. Tareq, "The Effect of Junior High School Teachers Motivation and Willingness to Change on the Diversity of Their Teaching Methods," Theory and Practice in Language Studies , vol. 7, no. 12, pp. 1160-1170, 2017.

[5] M. Callie, and S. Alexandra, "The Coupling of Second Language Learning Motivation and Achievement According to Gender," Theory and Practice in Language Studies, vol. 7, no.12, pp.1149-1159, 2017.

[6] M. Dodi, R. Dwi, and Y. Issy, "The Analysis of Students Listening Proficiency Viewed from Their Different Learning Style after Getting 
[17] E.A. Aziz, "Theorizing linguistic politeness in Indonesian society," Linguistik Indonesia, vol. 21, no. 2, pp. 167-187, 2003.

the Strategy Instruction," Theory and Practice in Language Studies, vol.7, no. 12, pp.1200- 1209, 2017.

[7] I.W. Rasna, “A Creative Construction Model of Language Acquisition in Linguistic Politeness for Elementary School Children Character Education," In 1st International Conference on Innovation in Education (ICoIE 2018). Atlantis Press, 2019.

[8] R. Relin, I.W. Rasna, and W.S. Binawati, "Values Implied in the Wratisasana Palm Manuscripts as Guideline of Politeness in Language of the Character Education: A Study of Theo-Ethno Pedagogy," Journal of Language Teaching and Research, vol. 9, no. 1, pp. 90-96, 2018.

[9] R. Relin, I.W. Rasna, and W.S. Binawati, "Local Wisdom Values in Balinese Folktales That Are Relevant to Character Education for the First Grade at Primary School," Journal of Language Teaching and Research, vol. 9, no. 1, pp. 155-163, 2018.

[10] I.W. Rasna and D.K. Tantra, "Reconstruction of Local Wisdom for Character Education through the Indonesia Language Learning: An Ethno-pedagogical Methodology," Theory and Practice in Language Studies, vol. 7, no. 12, pp. 1229-1235, 2017.

[11] R. Sibarani, Antropolinguistik: Antropologi Linguistik, Linguistik Antropologi. Poda, 2004.

[12] J. Willis, Strategi Pembelajaran efektif berbasis riset otak. Yogyakarta: Mitra Media, 2010.

[13] A. Aman, N. Setiawan and L. Yuliana, "Pengembangan Model Pendidikan Karakter sebagai Upaya Peningkatan Personal dan Social Skill Bagi Anak Jalanan di Daerah Istimewa Yogyakarta” Jurnal Pendidikan dan Kebudayaan, vol. 20, no. 3, pp. 423-439, 2014.

[14] Pranowo, Teori Belajar Bahasa. Yogyakarta: Pustaka Pelajar, 2014.

[15] D. Kartika, Budaya Malu dan Tindak Bertanya pada Pemelajar Program BIPA di Fakultas Ilmu Pengetahuan Budaya Universitas Indonesia dalam Proseding Komperensi Linguisti Atmajaya Tingkat Internasional 24-25 Februari 2004. Jakarta: Pusat Kajian Bahasa dan Budaya, 2004, p67-700.

[16] S. Darmojuwono, "Peran Unsur Etnopragmatis dalam Komunikasi Masyarakat Multikultural," Jurnal Ilmiyah masyarakat Linguistik Indonesia, 1, 19-34, 2011.
[18] S.N.W. Binawati, "Integrating the Philosophy of Tri Hita Karana into Indonesian Language Material Provision," Opcion,Ano, vol. 35, no. 89, pp. 72-91, 2019.

[19] Miles and Huberman, Analisis Data Kualitatif. Jakarta: GrafitiPress, 1994.

[20] C. Geertz, Kebudayaan dan Agama. Budisantoso (Sekapur Sirih). Yogyakarta:Kanisius, 1999.

[21] P.F. Carspecten, Critical Ethnography in Educational Research:A Theoritical an Practical Guide.London and New York: Roudledge.

[22] Y. Li, X. Wang, X.R. Zhu, Y.X. Zhu, and J. Sun, "Effectiveness of problem-based learning on the professional communication competencies of nursing students and nurses: A systematic review," Nurse education in practice, 2019.

[23] T. Guilfoos, H. Miao, S. Trandafir, and E. Uchida, "Social learning and communication with threshold uncertainty," Resource and Energy Economics, vol. 55, pp. 81-101, 2019.

[24] D.P. Tampubolon, Peran Bahasa dalam Memajukan Bangsa. Jurnal Bahasa dan Budaya, 2001.

[25] A. Chaer, Kesantunan Berbahasa. Jakarta: Rineka Cipta, 2010.

[26] M.C. Adam, "How to Do Things with Slurs: Studies in the Way of Derogatory Words," Science Direct Language and Commonication, vol. 33, no. 3, pp. 177-204, 2013.

[27] A.D. Askalemarian and A.S. Abatihun, "Moving Beyond a Sign of Jugdment: Primary School Teachers Perception and Practise of Feedback," International Journal ofInstuction, vol. 12, no.2, pp. 51-66, 2019.

[28] I.W. Rasna, Kualitas Bentuk Tuturan Guru sebagai Komunikasi Pendidikan dan efeknya terhadap Kualitas Belajar: Kajian Linguistik Pendidikan. Laporan Penelitian Program Pascasarjana. Tidak Diterbitkan, 2018. Ilmiah Masyarakat Linguistik Indonesia XIX. Jakarta: Pusat Kajian 